\title{
(2) OPEN ACCESS \\ Epidural infections, bacteriostatic drug effects and technical strategies for prevention
}

\author{
Joerg Bruenke (1) , ${ }^{1}$ Thomas Riemann, ${ }^{2}$ Paul Kessler, ${ }^{3}$ Norman Kachel ${ }^{2}$
}

${ }^{1}$ Dr. Brünke MTC e.K, Nuremberg, Germany ${ }^{2}$ B. Braun Melsungen AG, Melsungen, Hessen, Germany ${ }^{3}$ Department of Anesthesiology, University Hospital Frankfurt, Frankfurt, Germany

Correspondence to Dr Joerg Bruenke, Dr. Brünke MTC e.K., Nuremberg 90480 , Germany; jb@bruenke-mtc.de

Received 13 February 2021 Accepted 28 May 2021

\section{Check for updates}

(C) American Society of Regional Anesthesia \& Pain Medicine 2021. Re-use permitted under CC BY-NC. No commercial re-use. Published by BMJ.

\begin{tabular}{l}
\hline To cite: Bruenke J, \\
Riemann T, Kessler P, et al. \\
Reg Anesth Pain Med Epub \\
ahead of print: [please \\
include Day Month Year]. \\
doi:10.1136/rapm-2021- \\
102517
\end{tabular}

\section{INTRODUCTION}

Epidural infections are a rare but serious complication which can result in an irreversible neurological damage if not treated. Catheterization of the epidural space is routinely used in anesthesia and analgesia, which connects the epidural space with the outside environment, through which bacteria can gain access to the epidural space. ${ }^{1-3}$ Here, the use of epidural filter serves as a physical barrier to prevent ingress of bacteria through the infusion line. In this study, we investigated the survivability of seven typical pathogens in bupivacaine and ropivacaine when contaminated during manipulation (eg, local anesthesia (LA) bolus application/infusion) and the ability of an epidural flat filter to prevent microbial transmission by a contaminated infusion solution until physical occlusion of the filter.

\section{METHODS}

The survivability of seven typical deviceassociated pathogens was tested by artificial microbial contamination $\left(1.25 \times 10^{5}\right.$ colonyforming units $(\mathrm{CFU}) / \mathrm{mL}$ ) of different concentrations of two commonly used epidural anesthetics, bupivacaine and ropivacaine. The number of vital micro-organisms was checked daily over a period of 4 days by plating out aliquots and CFU counting.

The maintenance of the microbial barrier function of a $0.2 \mu \mathrm{m}$ epidural catheter filter (Perifix from B. Braun) was investigated by the presence of microbial contamination in the flow-through solution after challenging the filter with an artificially contaminated infusion solution with test bacteria Staphylococcus aureus or Pseudomonas aeruginosa by a volumetric infusion pump at a speed of $10 \mathrm{~mL} /$ hour until automated pressure shutdown was observed due to physical/mechanical occlusion of the filter by bacteria.

\section{RESULTS}

Microbial survivability in anesthetics bupivacaine and ropivacaine

The number of vital organisms in the anesthetics bupivacaine and ropivacaine was reduced over time. However, some pathogens (S. aureus, $P$. aeruginosa and Candida albicans) were able to survive to a certain degree over the test period of 4 days (figure 1 ).

\section{Microbial tightness of epidural filter}

For physical occlusion of a $0.2 \mu \mathrm{m}$ epidural flat filter by micro-organisms, a relatively high number of bacteria $\left(\geq 5.5 \times 10^{8}\right.$ CFUs) were required for both tested micro-organisms, $S$. epidermidis and $P$. aeruginosa, respectively. The filter maintained its microbial barrier function even after physical occlusion as no bacteria were detectable in the flow-through fraction (figure 2). The level of vital bacteria remained comparable throughout the test.

\section{DISCUSSION}

This in vitro study demonstrated that different typical device-associated pathogens can survive over a period of several days directly in the anesthetic solutions bupivacaine and ropivacaine. Furthermore, it was shown that an $0.2 \mu \mathrm{m}$ epidural flat filter can efficiently prevent microbial transmission even when challenged with high numbers of bacteria until physical occlusion and pressure shutdown was achieved.

It was shown that ropivacaine exhibited poor antibacterial activities, ${ }^{4-6}$ whereas bupivacaine showed concentration-dependent antibacterial activity. ${ }^{4}$ While other studies investigated on antibacterial activity in the presence of growth medium, our study focused on the ability to survive directly in the anesthetic solution simulating microbial contamination during drug admixture.

Maintaining filter integrity and microbial tightness even when physical occlusion by microorganism is achieved has not been reported so far. Interestingly, the number of micro-organisms leading to physical occlusion of the epidural filter was observed with a very high concentration of bacteria ( $\left.>10^{8} \mathrm{CFU}\right)$.

Noteworthy, the contamination level chosen in this study was higher than that in a normal clinical environment in order to determine the required bioburden to obtain physical occlusion of the epidural filter. The results of our investigation demonstrate that microbial barrier function was even sustained when physical occlusion of the peridural flat filter by $>10^{8}$ bacteria was attained. Thus, the duration time of epidural flat filters is not limited by time but mainly by the flow rate, which is influenced by the number of germs, particles and air which can block the membrane mechanically. Thus, the recommendation is to keep the system closed as long as technically possible (closed system). However, 
A Staphylococcus epidermidis

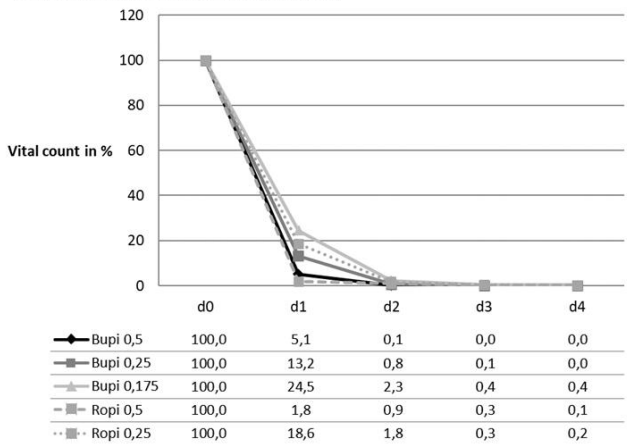

C Pseudomonas aeruginosa

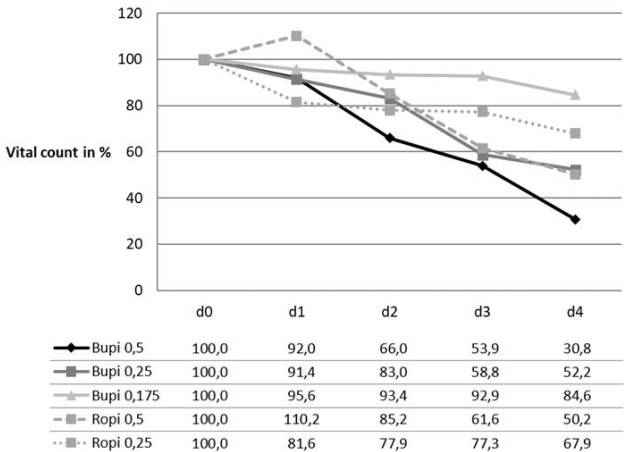

E Enterococcus faecalis

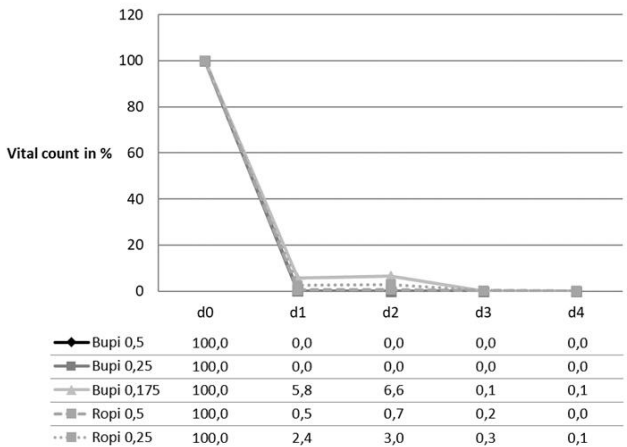

G Candida albicans

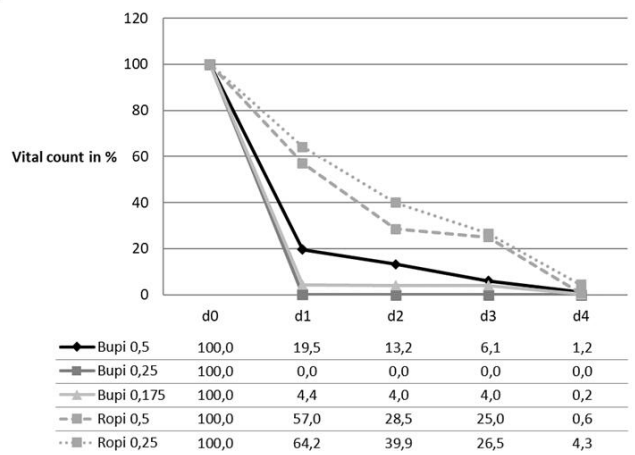

B Staphylococcus aureus MRSA

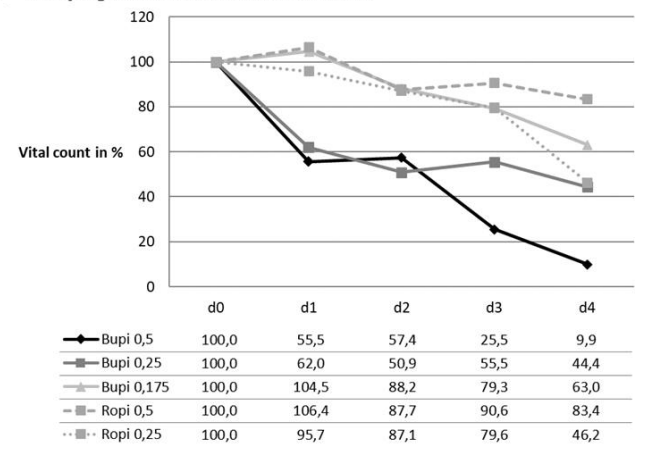

D Escherichia col

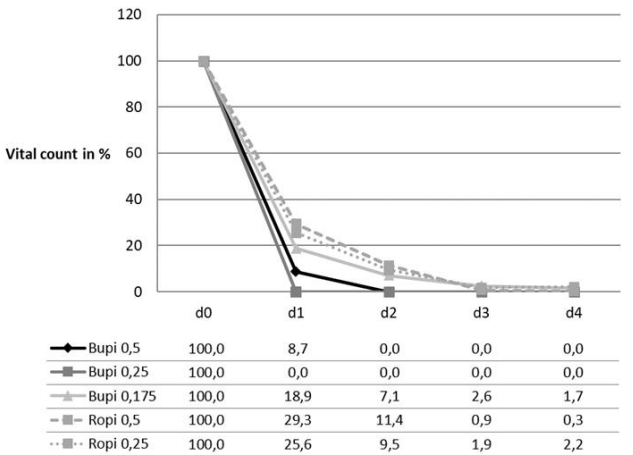

F Streptococcus pneumoniae

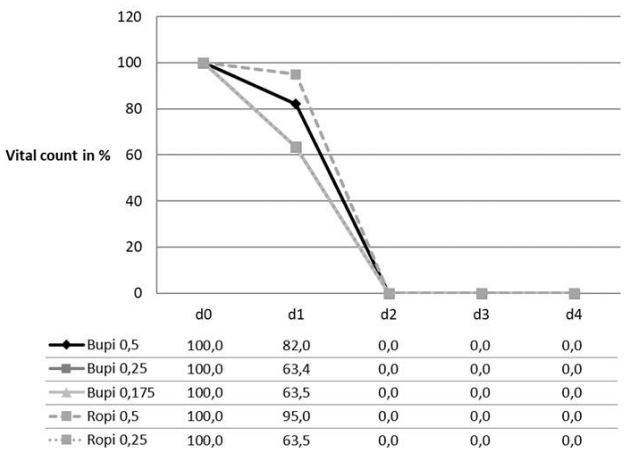

Figure 1 Viability of microorganisms in the anesthetic solutions bupivacaine and ropivacaine over a period of 4 days; the survivability of microorganisms in the anesthetics, bupivacaine and ropivacaine, respectively, was tested using seven different microbial strains, often found in deviceassociated infections. The spectrum of species included four Gram-positive strains (Staphylococcus epidermidis DSM 18857, S. aureus MRSA DSM 21979, Enterococcus faecalis DSM 2570/ATCC 29212 and Streptococcus pneumoniae DSM 11867), two Gram-negative bacterial strains (Pseudomonas aeruginosa DSM 939/ATCC 15442 and Escherichia coli DSM 1576/ATCC 8739) and one yeast (Candida albicans DSM 5817/ATCC 10259). The vitality of all test organisms in the anesthetic solutions bupivacaine $(0.5 \%, 0.25 \%$ and $1.75 \%$ solution) and ropivacaine $(0.5 \%$ and $0.25 \%$ solution) was determined every day over a period of 4 days by serial dilution plating of a $1 \mathrm{~mL}$ aliquot of the inoculated anesthetic solution. The data were from two individual experiments and normalized to the number of vital bacteria at test start (d0). 
A Staphylococcus epidermidis

\begin{tabular}{|c|c|c|c|c|c|}
\hline & $\begin{array}{l}\text { Infusion solution with } \\
\text { test bacteria }\end{array}$ & Test start & After $250 \mathrm{ml}$ & $\begin{array}{l}\text { After physical } \\
\text { occlusion }\end{array}$ & $\begin{array}{l}\text { Infusion solution } \\
\text { after physical } \\
\text { occlusion }\end{array}$ \\
\hline \multicolumn{6}{|c|}{ Agar Plate } \\
\hline $\mathrm{CFU} / \mathrm{ml}$ & $2.0 \times 10^{6}$ & 0 & 0 & 0 & $1.9 \times 10^{6}$ \\
\hline \multicolumn{6}{|c|}{ Pseudomonas aeruginosa } \\
\hline & $\begin{array}{l}\text { Infusion solution with } \\
\text { test bacteria }\end{array}$ & Test start & After $250 \mathrm{ml}$ & $\begin{array}{l}\text { After physical } \\
\text { occlusion }\end{array}$ & $\begin{array}{c}\text { Infusion solution } \\
\text { after physical } \\
\text { occlusion }\end{array}$ \\
\hline \multicolumn{6}{|l|}{ Agar Plate } \\
\hline $\mathrm{CFU} / \mathrm{ml}$ & $1.9 \times 10^{6}$ & 0 & 0 & 0 & $1.9 \times 10^{6}$ \\
\hline
\end{tabular}

Figure 2 Microbial tightness testing: microbial evaluation of flow-through samples. The epidural flat filter was challenged with an infusion solution artificially contaminated with $\sim 2.0 \times 10^{6} \mathrm{CFU} / \mathrm{mL}$ until the automated infusion system shut down to overpressure due to physical occlusion caused by the test bacteria in the infusion solution. At different time points (test start, after $250 \mathrm{~mL}$ and after physical occlusion), aliquots from the solution that passed the epidural flat filter were plated out on plate count agar plates, and the number of CFUs was determined after incubation at $37^{\circ} \mathrm{C}$ for a day. To prove the vitality of the test organism throughout the test procedure, the number of bacteria was also determined in the infusion solution at test start and after the filter was physically occluded. Physical occlusion of the $0.2 \mu \mathrm{m}$ epidural flat filter was achieved at a relatively high number of

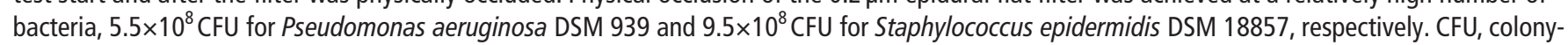
forming unit.

this study investigated selected aspects of the epidural filter in an in vitro setup and, thus, the behavior in an in vivo clinical environment could be different and has to be further investigated in clinical settings.

Contributors JB and TR designed the experiments. JB performed the experiments and took the lead in writing the manuscript. NK and PK contributed to the interpretation of the results. All authors provided critical feedback and helped shape the research, analysis and manuscript.

Funding This study was funded by B. Braun Melsungen AG, Melsungen, Germany. Competing interests None declared.

Patient consent for publication Not required.

Provenance and peer review Not commissioned; externally peer reviewed.

Open access This is an open access article distributed in accordance with the Creative Commons Attribution Non Commercial (CC BY-NC 4.0) license, which permits others to distribute, remix, adapt, build upon this work non-commercially, and license their derivative works on different terms, provided the original work is properly cited, an indication of whether changes were made, and the use is noncommercial. See: http://creativecommons.org/licenses/by-nc/4.0/.

\section{ORCID ID}

Joerg Bruenke http://orcid.org/0000-0002-0368-962X

\section{REFERENCES}

1 Kindler CH, Seeberger MD, Staender SE. Epidural abscess complicating epidural anesthesia and analgesia. An analysis of the literature. Acta Anaesthesio/ Scand 1998:42:614-20.

2 Dawson S. Epidural catheter infections. J Hosp Infect 2001;47:3-8.

3 van Samkar G, Balraadjsing PPS, Hermanns H, et al. Microbiological and scanning electron microscopic evaluation of epidural catheters. Reg Anesth Pain Med 2020;45:381-5.

4 Coghlan MW, Davies MJ, Hoyt C, et al. Antibacterial activity of epidural infusions. Anaesth Intensive Care 2009;37:66-9.

5 Pere $\mathrm{P}$, Lindgren L, Vaara M. Poor antibacterial effect of ropivacaine: comparison with bupivacaine. Anesthesiology 1999;91:884-6.

6 Aydin ON, Eyigor M, Aydin N. Antimicrobial activity of ropivacaine and other local anaesthetics. Eur J Anaesthesiol 2001;18:687-94. 